\title{
Two New Species of Nomimoscolex (Cestoda: Proteocephalidea, Monticelliidae) from Gymnotus carapo (Pisces: Gymnotiformes) in Argentina
}

\begin{abstract}
Alicia A Gil de Pertierra
Laboratorio de Helmintología, Departamento de Biodiversidad y Biología Experimental, Facultad de Ciencias Exactas y Naturales, Ciudad Universitaria, Pab. II, $4^{\circ}$ Piso, Universidad de Buenos Aires, C1428EHA, Buenos Aires, Argentina

Nomimoscolex guillermoi $n$. $s p$. and N. dechambrieri $n$. $s p$. are described from the gymnotiform fish Gymnotus carapo from Argentina. The new species are placed into Nomimoscolex based on the cortical position of the vitelline follicles, and medullary position of the testes, ovary, and uterus. Both species were compared to the 13 species considered valid in the genus. The combination of features distinguishing N. guillermoi from N. dechambrieri is (1) the position of the vagina to cirrus pouch (anterior or posterior vs always anterior respectively), (2) the total number of testes (41-85 vs 108-130 respectively), (3) the distribution of the vitelline follicles (arranged in dorsolateral and ventro-lateral bands vs lateral bands respectively), (4) the length of the uteroduct (ending $58 \%$ vs $35 \%$ from posterior margin of mature proglottis respectively), and (5) the presence of gland cells in the scolex (unicellular glands in the apical region and the external margin of suckers vs the presence of unicellular glands in the apex and other grouped in a cluster medially to the suckers respectively).
\end{abstract}

Key words: Nomimoscolex guillermoi n. sp. - Nomimoscolex dechambrieri n. sp. - Gymnotidae - cestodes - Argentina

Freshwater fish tapeworms in South America are mostly represented by cestodes of the order Proteocephalidea Mola, 1928. The larger diversity of proteocephalids occurs in siluriform fishes (Freze 1965, de Chambrier \& Vaucher 1999, Rego et al. 1999a). However, other groups of non-siluriform freshwater fishes as the Atheriniformes (Atherinidae), Characiformes (Characidae, Erythrinidae), Gymnotiformes (Gymnotidae) and Perciformes (Cichlidae), have been found to harbour proteocephalid cestodes (Rego \& Pavanelli 1990, Pavanelli \& Takemoto 1995, de Chambrier et al. 1996, Scholz et al. 1996, Takemoto \& Pavanelli 1996, de Chambrier \& Vaucher 1999, Gil de Pertierra \& Viozzi 1999, Rego et al. 1999b). In the gymnotid fish Gymnotus carapo Linnaeus, 1758, only one species of monticeliid, Nomimoscolex chubbi (Pavanelli \& Takemoto 1995) has been reported (Rego et al. 1999a). New collections of parasites of G. carapo in Argentina revealed the presence of three species of proteocephalid cestodes. Among them, two represent new species of Nomimoscolex Woodland, 1934 and are described herein. The third species is conspecific with N. chubbi described by Pavanelli and Takemoto (1995) from Brazil and represent a new geographic location for this species.

\section{MATERIALS AND METHODS}

Eighteen specimens of $G$. carapo captured in Colastiné River (near Santo Tomé), Santa Fe Province, Argentina were examined for helminths. Worms found in the intestine were isolated and fixed in hot $4 \%$ formaldehyde solu-

Financial support ANPCyT (Proj. BID 1201 OC-AR PICT No. 1-6604)

Fax:+54-11-4576.3384. E-mail: helminto@bg.fcen.uba.ar

Received 3 September 2002

Accepted 21 January 2003 tion and stored in $75 \%$ ethanol. Entire tapeworms were stained with Langeron's alcoholic chlorhydric carmine (Langeron 1949), differentiated in acid ethanol, dehydrated through a graded ethanol series, cleared in beechwood creosote and mounted as whole mounts in Canada balsam. Thick cross hand-cutting sections of the proglottides were stained following the same procedure. Whole mounts were studied using Nomarski interference contrast in a Zeiss Axioskop microscope. All drawings were made with the aid of a camera lucida. The specimens studied have been deposited at the "Colección Nacional de Parasitología”, Museo Argentino de Ciencias Naturales "Bernardino Rivadavia", Buenos Aires, Argentina (MACN-Pa). Type specimen of $N$. chubbi housed at Instituto Oswaldo Cruz Collection, Rio de Janeiro, Brazil (CHIOC) 33189 a-b (paratype) has also been studied. All measurements are given in micrometers, unless otherwise stated, with the range followed by the mean, and the number of measurements (n) in parentheses. The terms prevalence and intensity of infection are used according to Bush et al. (1997).

\section{RESULTS}

MONTICELLIIDAE La Rue, 1911

ZYGOBOTHRIINAE Woodland, 1933

Nomimoscolex guillermoi $\mathrm{n}$. sp.

(Figs 1-5)

Host: Gymnotus carapo Linnaeus, 1758 (Gymnotiformes: Gymnotidae), vernacular names: morena, morena pintada, anguiya flecuda

Locality: Santo Tomé (Río Colastiné) (31 $\left.30^{\circ} 40^{\prime} \mathrm{S} ; 60^{\circ} 46^{\prime} \mathrm{W}\right)$,

Provincia de Santa Fe, Argentina (1/8/2001)

Site of infection: intestinal caeca

Prevalence: $5.55 \%$

Intensity of infection: 1

Specimen deposited: MACN-Pa 417 (holotype) 
Etymology: the new species is dedicated to my husband Guillermo Pertierra for his continuous encouragement of my work, and in particular for his enthusiastic collaboration in the graphic design of the plates.

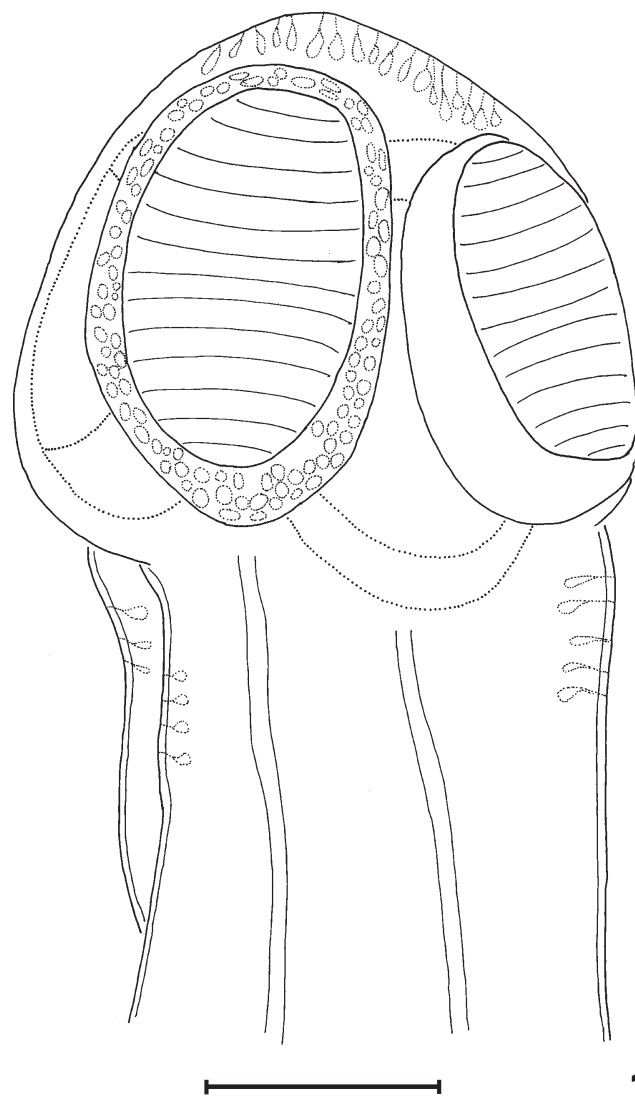

Description (based on one specimen): testes, ovary, uterus medullary, vitelline follicles cortical. Worm of medium size, total length $133 \mathrm{~mm}$, flattened dorsoventrally. Strobila acraspedote, bearing 196 proglottides, 65 imma-

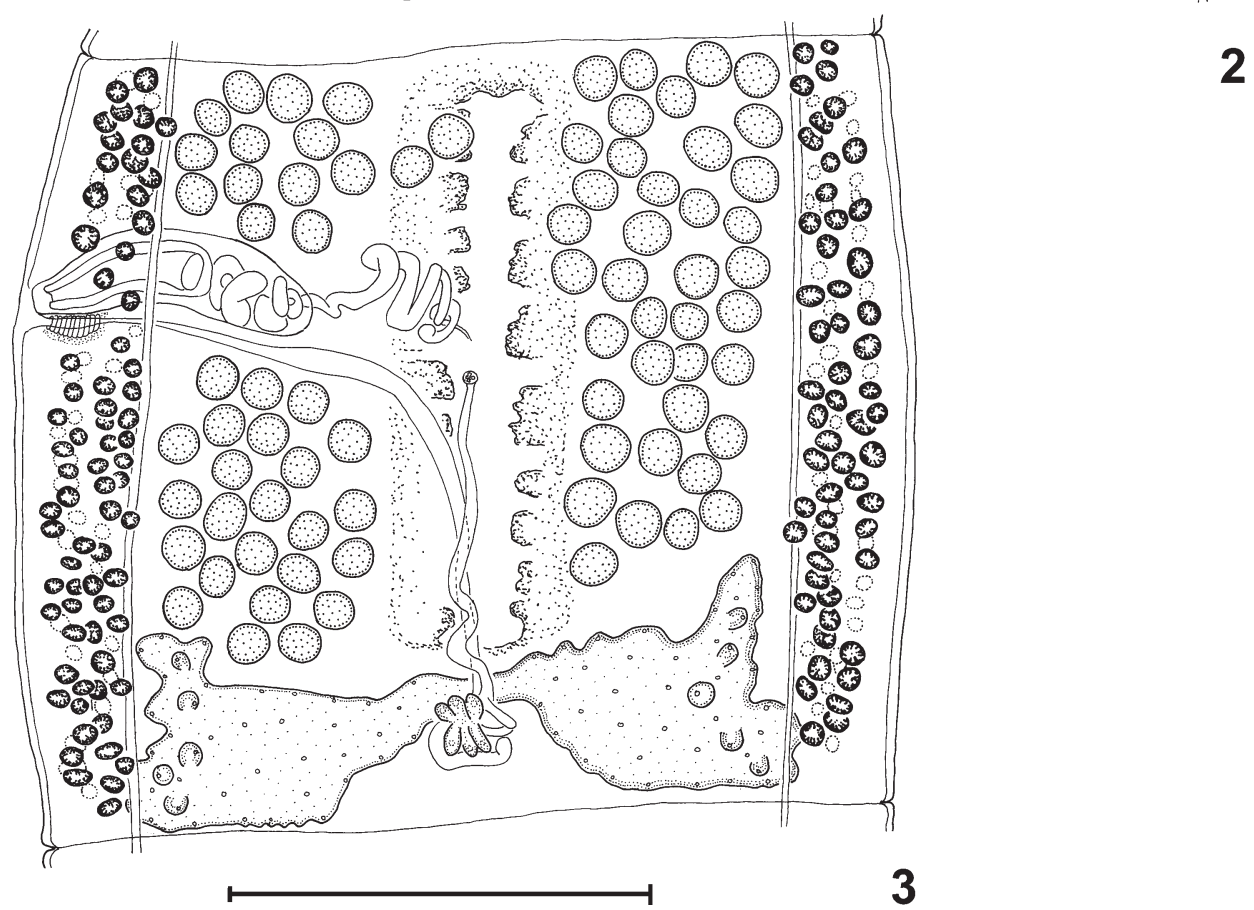

Nomimoscolex guillermoi $\mathrm{n}$. sp. Fig. 1: scolex, showing gland cells in the apical region, external margin of sucker (only drawn in one of the suckers), and proliferation zone. Bar $=100 \mu \mathrm{m}$. Fig. 2: gravid proglottis, ventral view. Bar $=500 \mu \mathrm{m}$. Fig. 3: mature proglottis, dorsal view. $\mathrm{Bar}=500 \mu \mathrm{m}$ 
ture proglottides, 48 mature proglottides, and 83 gravid proglottides.

Scolex wider than proliferation zone (Fig. 1), 280 wide, with small bottle-shaped glandular cells distributed in apical region, and all around the external margins of suckers. Suckers unilobate, uniloculate, strongly muscular, 200$210(\mathrm{n}=4)$ long, 150 wide. Proliferation zone (neck) $3.5 \mathrm{~mm}$ long, 200 wide; unicellular glands present. Immature proglottides wider than long, 130-700 (310; $\mathrm{n}=7)$ long, 230730 (413) wide. Mature proglottides wider than long (Fig. 3 ) or quadrangular, 650-950 $(770 ; \mathrm{n}=15)$ long, 790-1060 (910) wide; gravid proglottides longer than wide (Fig. 2) or wider than long, 1020-1320 $(1180 ; \mathrm{n}=12)$ long, $910-1330$ (1020) wide.

Osmoregulatory canals laterally situated between testes and vitelline follicles, dorsal canals 8-10 in diameter, ventral canals 15-20 in diameter. Internal longitudinal musculature well developed, forming a thick bundle of thick muscular fibres (Figs 4-5).

Testes medullary, spherical $60-90(70 ; n=10)$ in diameter, total number $41-85(63 ; n=9)$ in mature proglottides, in one layer (Figs 3, 5), arranged in two fields connected anterioly by $1-2$ testes; testicular field separated from vitelline follicles by dorsal and ventral osmoregulatory canals (Fig. 5). Cirrus pouch elongate or pyriform, with thin muscular wall, 210-350 (297; $\mathrm{n}=15)$ long, 50-110 (80) wide in mature proglottides; occupying $27-37 \%(33 \% ; n=15)$ of proglottis width in mature proglottides, and $32-38 \%$ $(36 \% ; n=12)$ in gravid proglottides. Genital pores irregu- larly alternating, at $25-40 \%(32 \% ; \mathrm{n}=15)$ from anterior margin of mature proglottis. Vas deferens weakly coiled, 30-60 in diameter, usually not surpassing body midline in mature proglottides (Fig. 3).

Vagina thick-walled, anterior $(84 \% ; n=83)$ or posterior $(16 \%)$ to cirrus pouch, $10-30$ in diameter; when the vaginal canal is anterior, ventrally overlapping cirrus pouch, not surrounding vas deferens. Vaginal sphincter present. Vaginal canal dorsal to uterus emerging dorsally to ovarian isthmus. Ovary medullary, with 2 lobulate lateral lobes, lobules developed dorsally, 120-220 $(158 ; n=$ 15) long, 500-760 (630) wide, occupying $63-76 \%$ (69\%; $n=$ 15 ) of proglottis width in mature and gravid proglottides (Figs 2-4). Ovary in gravid proglottides usually expands anterioly, 220-350 (275; $\mathrm{n}=12)$ long, 600-950 (705) wide. Mehlis'glands 80-120 long, 80-110 wide. Vitelline follicles cortical, some follicles slightly paramuscular; in two dorsolateral and ventro-lateral bands, not interrupted by vagina and cirrus pouch dorsally, reaching $98-100 \%$ of total proglottis length.

Uterine primordium originated as a cortical cylindrical mass of chromophil cells in immature proglottides. Uterine branches developed in medulla (Fig. 4), not overlapping ovary ventrally in gravid proglottides (Fig. 2). Medullary uterine branches occupying $40-50 \%(44 \% ; n=12)$ of gravid proglottis width; 18-23 $(\mathrm{n}=12)$ lateral branches opposite to cirrus pouch and 16-20 on cirrus pouch side. Uteroduct very long (388 long, 20 in diameter), ending up to $58 \%$ from posterior margin of mature proglottis (Fig. 3).

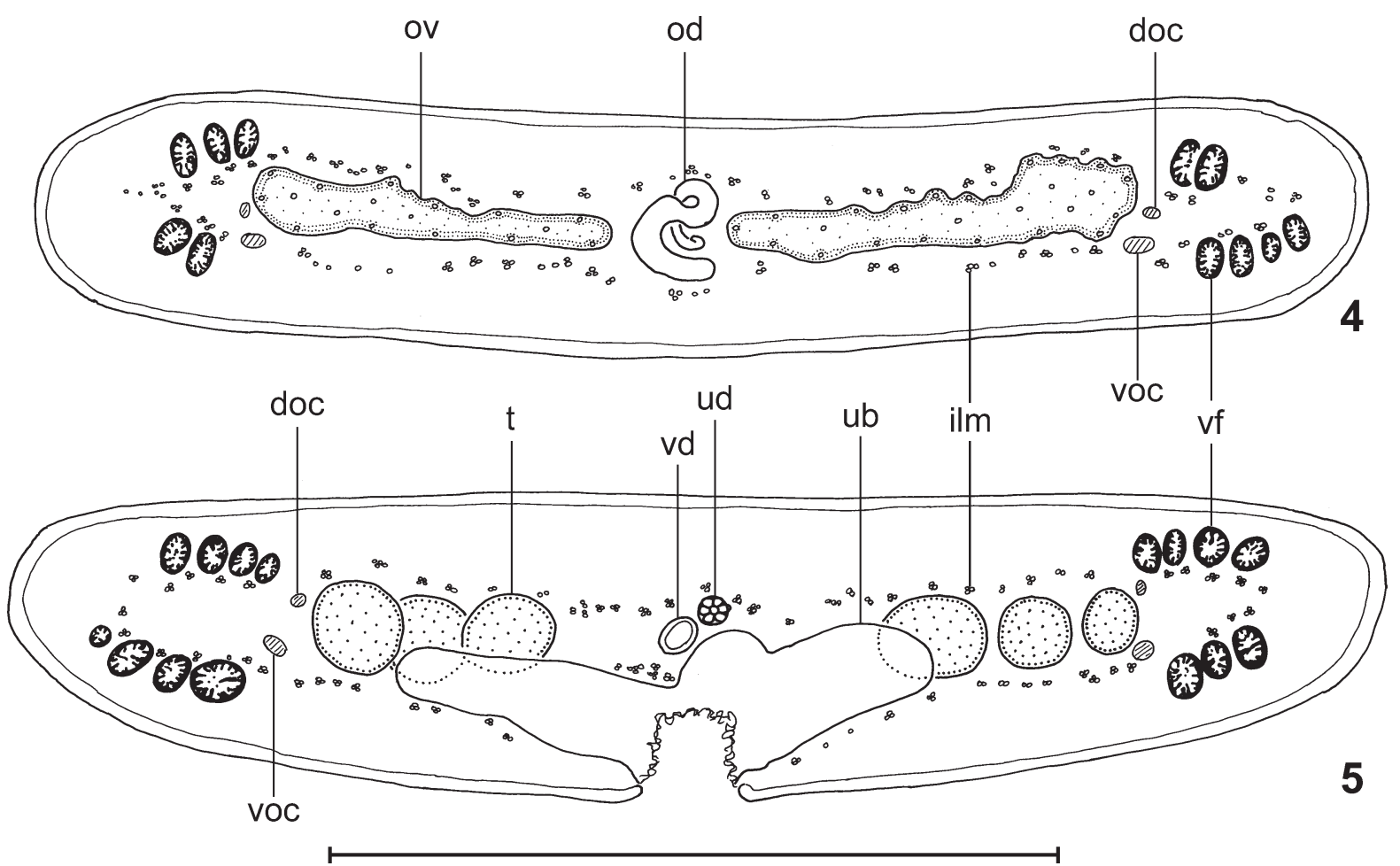

Nomimoscolex guillermoi $\mathrm{n}$. sp. Cross-sections of proglottides. Fig. 4: cross-section at level of the ovary posterior to the isthmus. Bar $=$ $500 \mu \mathrm{m}$. Fig. 5: cross-section of gravid proglottis posterior to the cirrus pouch and anterior to the ovary. Bar $=500 \mu \mathrm{m}$. doc: dorsal osmoregulatory canal; ilm: internal longitudinal musculature; od: oviduct; ov: ovary; t: testis; ub: uterine branches; ud: uteroduct; vd: vaginal duct; vf: vitelline follicles; voc: ventral osmoregulatory canal 
Mature eggs released by a wide ventral oval longitudinal slit.

Differential diagnosis: the genus Nomimoscolex includes 13 species: $N$. admonticellia (Woodland, 1934), $N$. brooksi (García-Prieto, Rodríguez \& Pérez-Ponce de León, 1996) (see Scholz et al. 2001, Gil de Pertierra 2002), $N$. chubbi (Pavanelli \& Takemoto, 1995), N. dorad (Woodland, 1935), N. lenha (Woodland, 1933), N. matogrossensis Rego \& Pavanelli, 1990, N. microacetabula Gil de Pertierra, 1995, N. lopesi Rego, 1989, N. piraeeba Woodland, 1934, N. semenase Gil de Pertierra, 2002, N. sudobim Woodland, 1935, N. suspectus Zehnder, de Chambrier, Vaucher \& Mariaux, 2000, and N. touzeti de Chambrier \& Vaucher, 1992; 12 from South America (one of them in amphibians), and one in the Northern hemisphere.

$N$. guillermoi $\mathrm{n}$. sp. can be distinguished from all other species of the genus by the following combination of characters: (1) absence of an apical organ, (2) strobila acraspedote, (3) vagina anterior or posterior to cirrus pouch, having sphincter, (4) testes in one layer and in two fields, sometimes connected anteriorly by $1-2$ testes, and (5) uterine stem cortical in immature proglottides, growing from cortical stem into ventral medullary region in mature proglottides.

The new species resembles $N$. admonticellia, $N$. brooksi, N. chubbi, N. dorad, N. lenha, N. matogrossensis, $N$. microacetabula, $N$. piraeeba, $N$. semenasae, and $N$. suspectus in the development of the uterus, cortical in immature proglottides and invading the medulla in mature proglottides. However, N. guillermoi can be distinguished from $N$. admonticellia, $N$. dorad, $N$. matogrossensis, $N$. piraeeba and $N$. suspectus by the absence of an apical organ, and from N. chubbi, N. lenha and $N$. microacetabula by the position of the vagina to the cirrus pouch (anterior or posterior in N. guillermoi vs always posterior in all other species), and from $N$. brooksi and $N$. semenasae by the width of scolex (110-210 and $340-480$ respectively vs 280 in $N$. guillermoi) and number of testes (108-175 and 77-149 respectively vs 41-85 in $N$. guillermoi). Moreover, $N$. dorad, $N$. piraeeba and $N$. suspectus have craspedote strobilae (vs acraspedote strobila in $N$. guillermoi), while in $N$. admonticellia the strobila is slightly craspedote. $N$. sudobim Woodland, 1935 can be differentiated from $N$. guillermoi in having the vagina anterior to the cirrus pouch, higher number of testes (200-250 vs 41-85), and in the development of the uterus (entirely cortical vs cortical and medullar in $N$. guillermoi). $N$. lopesi and $N$. touzeti differ from $N$. guillermoi in the development of the uterus, entirely medullar whereas it is cortical and medullar in N. guillermoi. $N$. lopesi and N. sudobim differ from N. guillermoi in the position of osmoregulatory canals (situated internally to the testicular field vs between vitelline follicles and testicular field respectively).

\section{Nomimoscolex dechambrieri $\mathrm{n}$. sp.}

(Figs 6-10)

Host: Gymnotus carapo Linnaeus, 1758 (Gymnotiformes: Gymnotidae), vernacular names: morena, morena pintada, anguiya flecuda

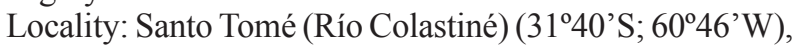

Provincia de Santa Fe, Argentina (15/02/2002)

Site of infection: intestinal caeca

Prevalence: $5.55 \%$

Intensity of infection: 1

Specimen deposited: MACN-Pa 418 (holotype)

Etymology: the new species is dedicated to Dr Alain de Chambrier of the Natural History Museum, Geneva, Switzerland for his contribution to proteocephalidean knowledge

Description (based on one specimen): testes, ovary, uterus medullary, vitelline follicles cortical. Worm of medium size, total length $132 \mathrm{~mm}$, flattened dorsoventrally. Strobila acraspedote, bearing 145 proglottides, 62 immature proglottides, 8 mature proglottides, and 75 gravid proglottides.

Scolex wider than proliferation zone (Fig. 6), 255 wide, with small bottle-shaped glandular cells distributed in apical region; numerous gland cells with granular inclusions, grouped in a cluster situated medially to the suckers, ducts not observed. Suckers unilobate, uniloculate, strongly muscular, 130-140 $(n=4)$ long, 85-95 wide.

Proliferation zone (neck) $2.5 \mathrm{~mm}$ long, 190 wide. Immature proglottides wider than long, $60-430(270 ; n=7)$ long, 210-520 (390) wide. Mature proglottides wider than long (Fig. 8) or longer than wide, 430-1000 $(700 ; n=5)$ long, 580-760 (660) wide; gravid proglottides longer than wide (Fig. 7) or wider than long, 980-1670 $(1382 ; \mathrm{n}=10)$ long, 910-1370 (1170) wide.

Osmoregulatory canals laterally situated, between testes and vitelline follicles, dorsal canals 5-15 in diameter, ventral canals 10-20 in diameter. Internal longitudinal musculature well developed, forming a thick bundle of thick muscular fibres, occasionally anastomosed (Figs 9-10).

Testes medullary, spherical 50-80 $(60 ; \mathrm{n}=10)$ in diameter, total number $108-130(118 ; n=6)$ in mature proglottides, in one layer (Figs 8, 10); arranged in two fields connected anteriorly by a few number of testes. Testicular field separated from vitelline follicles by dorsal and ventral osmoregulatory canals (Fig. 10). Cirrus pouch elongate to pyriform, with thin muscular wall, 160-320 (262; $\mathrm{n}=5$ ) long, 80-120 (96) wide, occupying $28-44 \%$ (39\%; $\mathrm{n}=$ 5 ) of proglottis width in mature proglottides, and $28-36 \%$ $(33 \% ; n=10)$ in gravid proglottides. Genital pores irregularly alternating, at $26-35 \%(30 \% ; n=5)$ from anterior margin of mature proglottis. Vas deferens coiled, 20-40 in diameter, forming a globular bulk, usually not surpassing body midline in mature proglottides (Figs 7-8).

Vagina thick-walled, always anterior to cirrus pouch, 10-30 in diameter; overlapping vas deferens, not surrounding it. Vaginal sphincter present. Vaginal canal dorsal to uterus emerging dorsally to ovarian isthmus. Ovary medullary, with 2 lobulate lateral lobes; $120-210(150 ; n=5)$ long, 410-560 (485) wide, occupying 71-77\% $(73 \% ; n=5)$ of proglottis width in mature proglottis (Figs 8-9). Ovary in gravid proglottides usually expands anteriorly, 240-470 (340; $\mathrm{n}=10)$ long, 690-1050 (905); occupying 67-85\% (77\%; $\mathrm{n}=10$ ) of proglottis width. Mehlis' glands 90-110 long, 80100 wide. Vitelline follicles cortical, some follicles slightly paramuscular; in two lateral bands, not interrupted by vagina and cirrus pouch dorsally, reaching $100 \%$ of total proglottis length. 
Uterine primordium originated as a cortical cylindrical mass of chromophil cells in immature proglottides. Uterine branches developed in medulla, not overlapping ovary ventrally in gravid proglottides (Figs 7, 10). Medullary

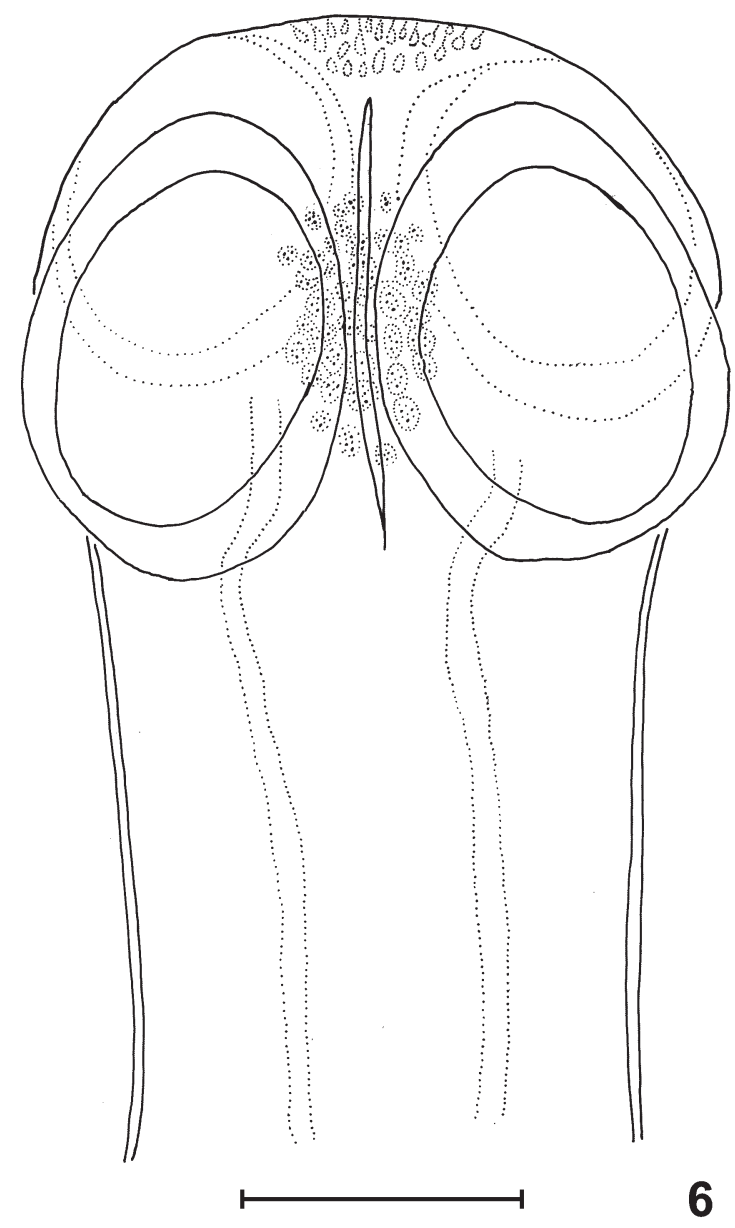

uterine branches occupying $27-56 \%(44 \% ; n=10)$ of gravid proglottis width, 16-24 $(\mathrm{n}=7)$ lateral branches opposite to cirrus pouch side and 12-20 on cirrus pouch side. Uteroduct 280 long, 20 in diameter, ending up to $35 \%$ from

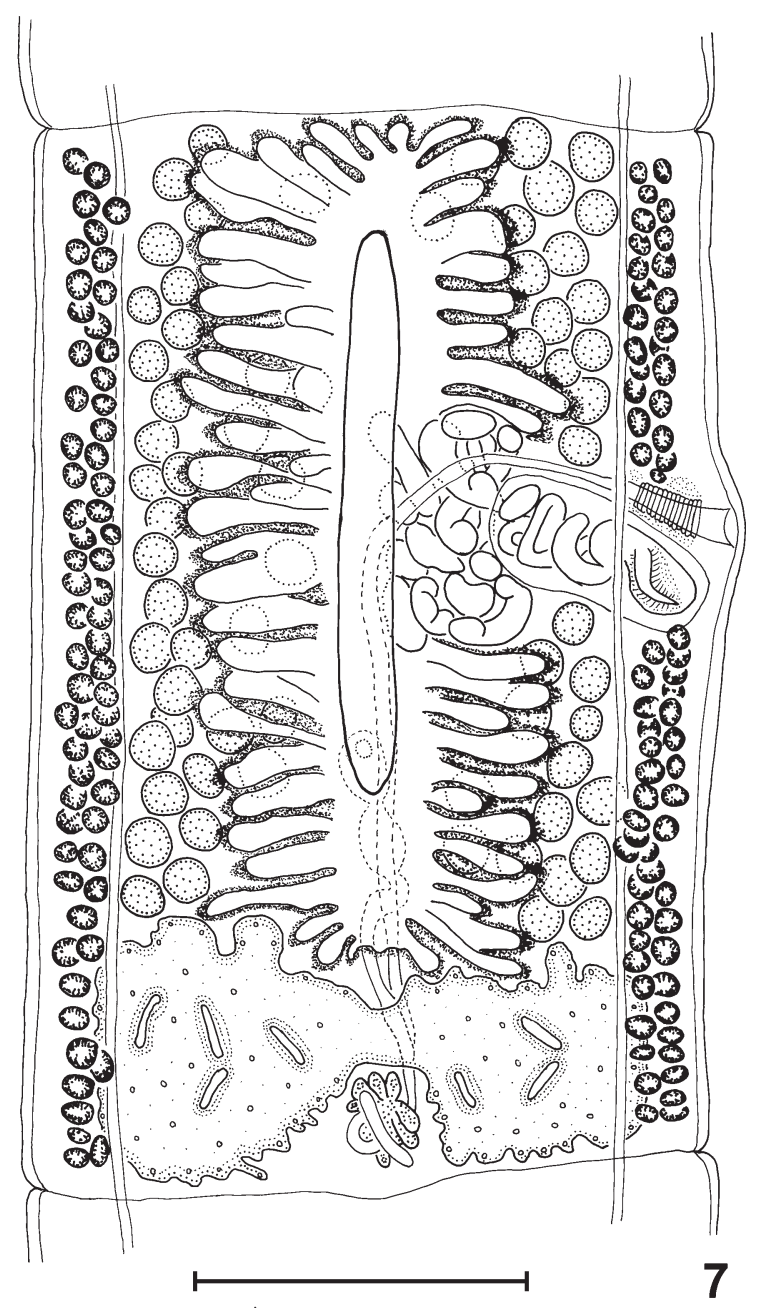

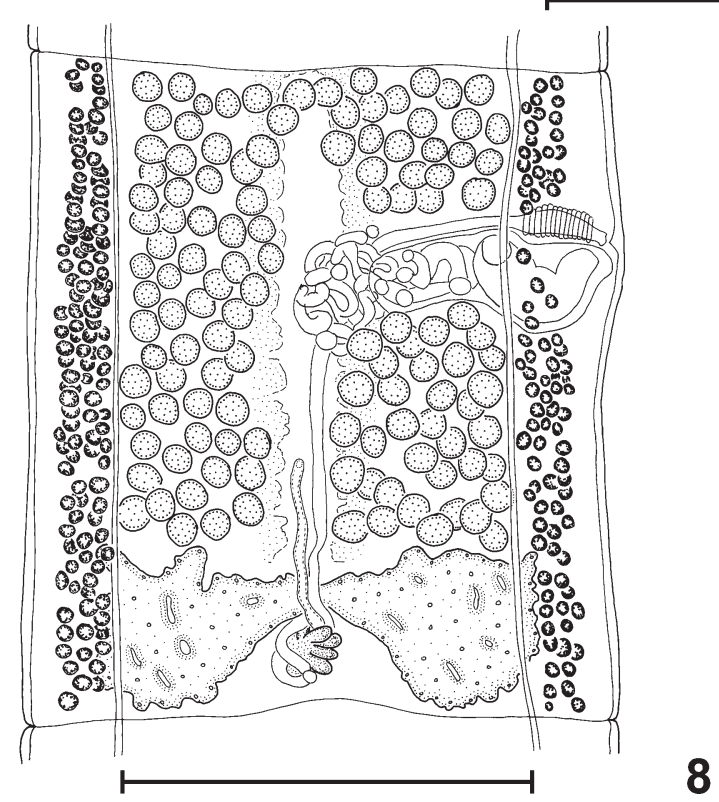

Nomimoscolex dechambrieri n. sp. Fig. 6: scolex, showing gland cells in the apical region and a raceme of gland cells situated posteromedially to the suckers. Bar $=100 \mu \mathrm{m}$. Fig. 7: gravid proglottis, ventral view. Bar $=500 \mu \mathrm{m}$. Fig. 8: mature proglottis dorsal view. Bar $=500 \mu \mathrm{m}$ 
posterior margin of mature proglottis. Mature eggs released by a wide oval ventral longitudinal slit.

Differential diagnosis: $N$. dechambrieri n. sp. can be distinguished from all other species in this genus by its possession of the following combination of features: (1) absence of an apical organ, (2) unicellular glands grouped in a cluster situated medially to the suckers, (3) strobila acraspedote, (4) vagina anterior to cirrus pouch, with sphincter, (5) testes in one layer and in two fields connected anteriorly by a few number of testes, and (6) uterine stem cortical in immature proglottides, growing from cortical stem into ventral medullary region in mature proglottides.

$N$. dechambrieri shares with $N$. admonticellia, $N$. brooksi, N. chubbi, N. dorad, N. lenha, N. matogrossensis, N. microacetabula, $N$. piraeeba, N. semenasae and $N$. suspectus the development of the uterus, cortical in immature proglottides and invading the medulla in mature proglottides. However, $N$. dechambrieri differs from $N$. admonticellia, $N$. dorad, $N$. mato-grossensis, $N$. piraeeba and $N$. suspectus by the absence of an apical organ, from $N$. chubbi, N. lenha and N. microacetabula by the position of the vagina to the cirrus pouch (always anterior in $N$. dechambrieri vs always posterior in all other species), and it is different from $N$. brooksi and $N$. semenasae in which the vagina is either anterior or posterior to the cirrus pouch. Moreover, $N$. dorad, $N$. piraeeba and $N$. suspectus have craspedote strobilae (vs acraspedote strobila in $N$. dechambrieri), and in $N$. admonticellia the strobila is slightly craspedote. N.lopesi and $N$. touzeti differ from $N$. dechambrieri in the development of the uterus, entirely medullar but cortical and medullary in $N$. dechambrieri. N. sudobim shares with $N$. dechambrieri the possession of a vagina anterior to the cirrus pouch, but they can be diffentiated by the development of the uterus (entirely cortical vs cortical and medullary in $N$. dechambrieri), and by the possession of higher number of testes (200-250 vs 108-130 in $N$. dechambrieri). $N$. lopesi and $N$. sudobim differ from $N$. dechambrieri in the position of osmoregulatory canals (situated internally to the testicular field vs between vitelline follicles and testicular field respectively).

$N$. guillermoi is similar to $N$. dechambrieri by: (1) the absence of an apical organ, (2) the strobila acraspedote, (3) the presence of the vaginal sphincter, (4) the possession of a thick bundle of longitudinal muscular fibres, (5) the development of the uterus, (6) a similar total number of uterine branches (34-43 and 28-44 respectively), (7) the position of the genital pores, anterior third of proglottis, $25-40 \%(32 \%)$ and $26-35 \%(30 \%)$ respectively, (8) the relation between ovary width and mature proglottis width, $63-76 \%(69 \%)$ and $71-77 \%(73 \%)$ respectively, (10) the testicular field, in 1 layer, and two fields connected anterioly by scarcely number of testes, and (11) the elimination of eggs by a ventral slit in the central zone of the proglottis.

$N$. guillermoi clearly differs from $N$. dechambrieri by: (1) the position of the vagina to cirrus pouch (anterior or posterior vs always anterior respectively), (2) the total

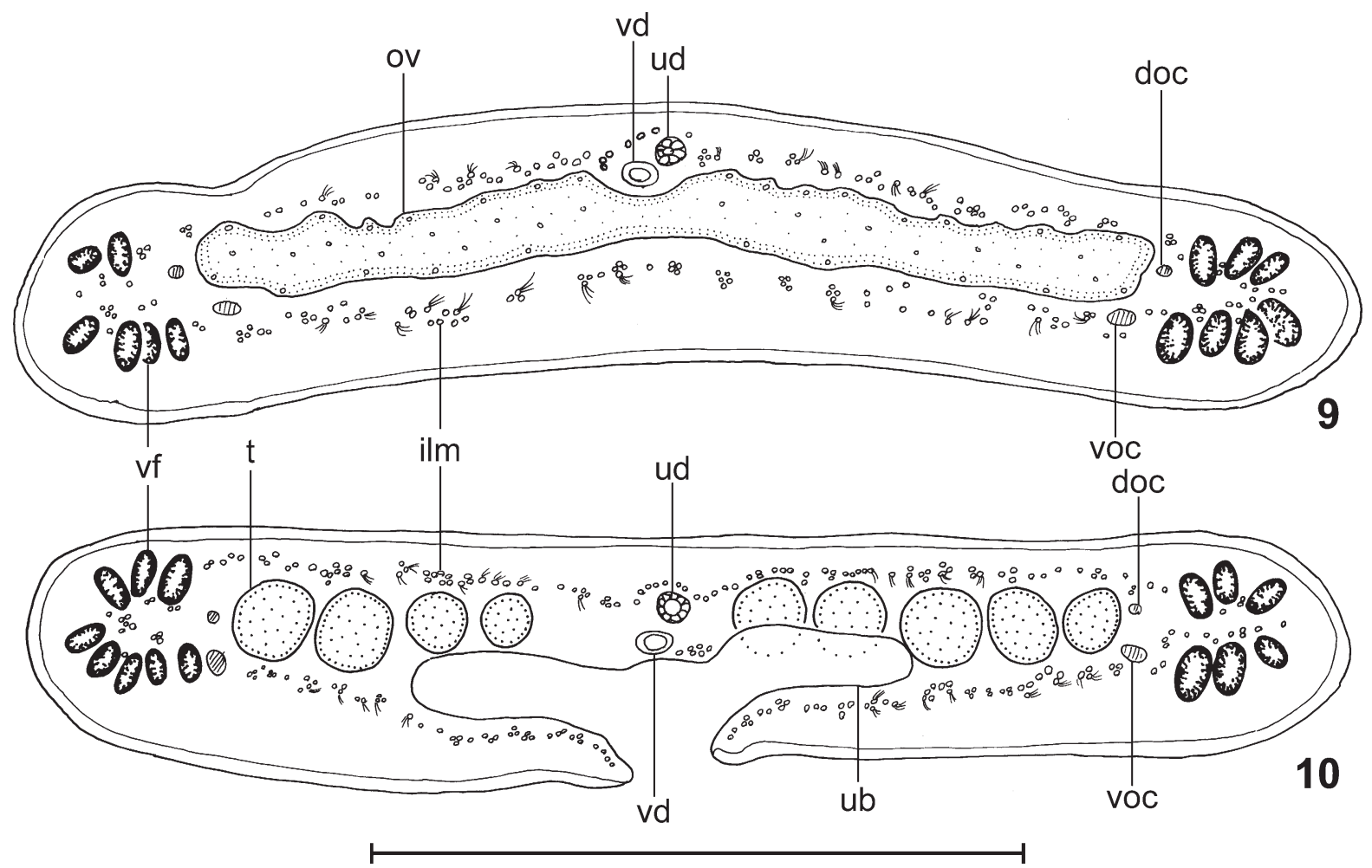

Nomimoscolex dechambrieri n. sp. Cross-sections of proglottides. Fig. 9: cross-section at level of the isthmus of the ovary. Bar $=500 \mu$ m. Fig. 10: cross-section of gravid proglottis posterior to the cirrus pouch and anterior to the ovary. Bar $=500 \mu \mathrm{m}$. doc: dorsal osmoregulatory canal; ilm: internal longitudinal musculature; ov: ovary; t: testis; ub: uterine branches; ud: uteroduct; vd: vaginal duct; vf: vitelline follicles; voc: ventral osmoregulatory canal 
number of testes (41-85 vs 108-130 respectively), (3) the vitelline follicles arranged in dorso-lateral and ventro-lateral bands vs lateral bands respectively, (4) the length of the uteroduct (ending $58 \%$ vs ending $35 \%$ from posterior margin of mature proglottis respectively), and (5) the presence of gland cells in the apical region of the scolex and external margin of suckers vs the presence of unicellular glands in the apex and others grouped in a cluster medially to the suckers respectively.

\section{DISCUSSION}

To date, few proteocephalid species are known from non-siluriform fishes from South America: 1 species in the family Atherinidae, 5 species in Characidae, 4 species in Cichlidae, 3 species in Erythrinidae, and 1 species in Gymnotidae. Only N. chubbi was described from Gymnotus carapo (Gymnotidae) in Paraná River, Brazil by Pavanelli and Takemoto (1995), and reported in Paraguay by de Chambrier and Vaucher (1999); in both studies the prevalence and intensity of infection was low. In the present study, 1 fish was parasitized by $N$. guillermoi and 1 fish was parasitized by $N$. dechambrieri. Due to the low prevalence and intensity of infection of proteocephalid cestodes in G. carapo, the descriptions were based on 1 specimen.

In conclusion, the species of Nomimoscolex parasitizing $G$. carapo could be separated by the following features: (1) the position of the vagina to cirrus pouch, (2) the total number of testes, (3) the distribution of testes, (4) the diameter of testes, and (5) the distribution of gland cells in the scolex.

\section{ACKNOWLEDGEMENTS}

To Dr Verónica Ivanov for valuable suggestions and for help in improving the English of the manuscript. To Dely Noronha, Instituto Oswaldo Cruz, for the loan of specimens.

\section{REFERENCES}

Bush AO, Lafferty KD, Lotz JM, Shostak AW 1997. Parasitology meets ecology on its own terms: Margolis et al. Revisited. J Parasitol 83: 575-583.

De Chambrier A, Vaucher C 1999. Proteocephalidae et Monticelliidae (Eucestoda: Proteocephalidea) parasites de poissons d'eau douce au Paraguay, avec descriptions d'un genre nouveau et de dix espèces nouvelles. Rev Suisse Zool 106: $165-240$.
De Chambrier A, Scholz T, Vaucher C 1996. Tapeworms (Cestoda: Proteocephalidea) of Hoplias malabaricus (Pisces: Characiformes, Erythrinidae) in Paraguay: description of Proteocephalus regoi sp. n., and redescription of Nomimoscolex matogrossensis. Folia Parasitol 43: 133-140.

Freze VI 1965. Essentials of Cestodology, Vol. 5, Proteocephalata in Fish, Amphibians and Reptiles. Moskva: Izdatel'stvo "Nauka", 538 pp. (In Russian: English translation by Israel Program of Scientific Translation, 1969, Cat. No. 1853, 597 pp.).

Gil de Pertierra AA 2002. Redescription of Proteocephalus bagri and P. rhamdiae (Cestoda: Proteocephalidae), parasite of Rhamdia quelen (Siluriformes: Pimelodidae) from South America, with comments on morphological variation. Folia Parasitol 49: 55-66.

Gil de Pertierra AA, Viozzi GP 1999. Redescription of Cangatiella macdonaghi (Szidat y Nani, 1951) comb. nov. (Cestoda: Proteocephalidae) a parasite of the Atheriniform fish Odontesthes hatcheri (Eigenmann, 1909) from the Patagonian region of Argentina. Neotrópica 45: 13-20.

Langeron M 1949. Précis de Microscopie, 7th ed., Masson \& Cie, Paris, 1429 pp.

Pavanelli GC, Takemoto RM 1995. New species of Proteocephalus (Cestoda - Proteocephalidae) parasitic in fishes from the Paraná river, Paraná, Brazil. Mem Inst Oswaldo Cruz 90: 593-596.

Rego AA, Pavanelli GC 1990. Novas espécies de cestóides proteocefalídeos parasitas de peixes não siluriformes. Rev Brasil Biol 50: 91-101.

Rego AA, Chubb JC, Pavanelli GC 1999a. Cestodes in South American freshwater teleost fishes: keys to the genera and brief description of species. Rev Brasil Zool 16: 299-367.

Rego AA, Machado PM, Pavanelli GC 1999b. Sciadocephalus megalodiscus Diesing, 1850 (Cestoda: Corallobothriinae), a parasite of Cichla monoculus Spix, 1831 (Cichlidae), in the Paraná river, State of Paraná, Brazil. J Helminthol 66: 133-137.

Scholz T, de Chambrier A, Prouza A, Royero R 1996. Redescription of Proteocephalus macrophallus, a parasite of Cichla ocellaris (Pisces: Cichlidae) from South America. Folia Parasitol 43: 287-281.

Scholz T, de Chambrier A, Salgado-Maldonado G 2001. Monticellia ophisterni n. sp. (Cestoda: Monticelliidae) from the swamp-eel Ophisternon aenigmaticum (Symbranchiformes) from Mexico. J Parasitol 87: 1328-1333.

Takemoto RM, Pavanelli GC 1996. Proteocephalidean cestodes in the freshwater fish Cichla monoculus from the Paraná river, Brazil. Stud Neotrop Fauna Environm 31 : 123-127. 
352 Two New Species of Nomimoscolex • Alicia A Gil de Pertierra 